Đordano Peršurić

Anita Silvana Ilak Peršurić
UDK: 634.8:582.783

DOI: http://doi.org/10.21857/y54jof6jpm

Izlaganje sa znanstvenog skupa

Rukopis prihvaćen za tisak: 14.9.2016.

\title{
GEN KOLEKCIJA AUTOHTONIH SORATA VINOVE LOZE U INSTITUTU, DOPRINOS ODRŽIVOM RAZVOJU VINOGRADARSTVA I VINARSTVA U ISTRI
}

\section{Sažetak}

Svjetski trend u očuvanju i održivom razvoju vinogradarstva već je niz godina baziran na izvornim i tipičnim sortama pojedinih vinogorja. Od 2003. godine u znanstvenim istraživanjima na projektu "Genetski i gospodarski resursi Vitis sp.“ (2001. - 2006.) i „Valorizacija resursa vinove loze (Vitis sp.) i banka gena" (2006. - 2012.) sustavno su se pratile autohtone sorte vinove loze na području Istre, $\mathrm{u}$ cilju njihovog pronalaženja te gospodarske i genetske valorizacije.

Tijekom 12-godišnjeg istraživanja, u kojem je učestvovala brojna ekipa istraživača i tehničkog osoblja Instituta, pregledano je stotinjak vinograda diljem Istarskog poluotoka, starih od 50 do 100 godina, cijepljenih na mjestu sadnje, u svrhu pronalaženja i identifikacije trsova svih starih istarskih sorata različitih genetskih i gospodarskih karakteristika. Na temelju pregleda i prikupljenih podataka iz osamdesetak nasada, označeno je više stotina biotipa različitih starih prepoznatljivih sorata vinove loze te puno biotipova sa zanimljivim ampelografskim karakteristikama koji se nisu mogli svrstati u do tada poznate stare sorte.

Svi označeni biotipovi ampelografski su identificirani i opisani. Njihove morfološke karakteristike opisane su pomoću OIV indikatora. Napravljene su i kemijske analize mošta ( $\mathrm{pH}$, šećeri, kiseline), te DAS-ELISA test, zbog utvrđivanja njihovog zdravstvenog stanja.

Najveći dio tih biotipova tijekom 2005. do 2012. godine posađen je u novom pokusnom nasadu Gen kolekcije autohtonih sorata vinove loze na imanju Instituta za poljoprivredu i turizam u Poreču. Na površini od $7.182 \mathrm{~m}^{2}$ nalazi se posađen 3.591 trs, uspješno razmnoženih biotipova. Taj nasad danas predstavlja osnovu za stvaranje novih klonova autohtonih sorata vinove loze u Istri.

Gen kolekcija Instituta osnova je za dugoročni i održivi razvoj vinogradarstva u Istri jer ne postoji niti jedan matični nasad vinove loze podignut sukladno važećim zakonskim propisima koji bi bio izvor kvalitetnog sadnog materijala autohtonih sorata genetskog porijekla iz Istre.

Ključne riječi: vinova loza; vinogradarstvo; autohtone sorte; gen kolekcija; održivi razvoj. 


\section{Uvod}

Razvoj komercijalnog vinogradarstva u svijetu u drugoj polovici 20. stoljeća preferirao je globalizaciju u izboru sortimenta vinove loze. Zbog takve politike razvoja samo je mali broj „svjetskih“ sorata bitno proširen po cijelom svijetu, a nestale su brojne autohtone sorte, posebno u razvijenim europskim zemljama. U manje razvijenima zemljama svijeta, pa tako i u Hrvatskoj, u napuštenim starim vinogradima ostalo je puno genetski vrijednog materijala koji može činiti osnovu modernog razvoja lokalnog vinogradarstva i vinarstva.

Na 28. Kongresu OIV-a u Beču (Austrija, srpanj 2004.), ta je svjetska organizacija utvrdila pravac daljnjeg razvoja vinogradarstva i vinarstva u svijetu. Od tada je svjetski trend u očuvanju i održivom razvoju vinogradarstva baziran na izvornim i tipičnim sortama pojedinih vinogorja. Osnovne postavke razvoja vinogradarstva i vinarstva definirane su pojmovima: nasljeđivanje, njegovanje, valorizacija i stvaranje, poticanje, valorizacija različitosti.

Vinovu lozu (Vitis sp.) karakterizira velika sortna i unutarsortna raznolikost, s puno autohtonih sorata, koje je potrebno lokalno pronaći i valorizirati pa to ugraditi u osnovu održivog razvoja poljoprivrednog prostora (Busnengo, 1998., Mannini, 2003).

Od pamtivijeka do danas, u Istri su vinogradarstvo i vinarstvo najvažnija grana poljoprivredne proizvodnje. Po podacima APPRRR-a za vinsku 2013. godinu, Istarska županija ima 12.107.339 trsova na 3.087 ha vinograda. Od sorata najzastupljenija je autohtona sorta Malvazija istarska s 1.696 ha (55\%) i 6.577 .591 trsom. Ostale sorte, po zastupljenosti u površinama od 316 do 100 ha su: Merlot, Teran, Cabernet sauvignon, Chardonnay i Refošk, dok su Borgonja, Muškat bijeli, Cabernet franc, Trebbiano Toscano i Muškat žuti zastupljene na površinama od 50 do 20 ha.

Od 2003. godine u znanstvenim istraživanjima Instituta za poljoprivredu i turizam u Poreču, na projektima „Genetski i gospodarski resursi Vitis sp.“ (2001. - 2006.) $\mathrm{i}$ „Valorizacija resursa vinove loze (Vitis sp.) i banka gena“ (2006. - 2012.) sustavno su se pratile autohtone sorte vinove loze na području Istre, u cilju njihovog pronalaženja te gospodarske i genetske valorizacije. Ovi projekti nastavak su ranijih istraživanja u Institutu resursa vinove loze u Istri (Bratović i sur., 2000., Milotić i sur., 1999., Ilak Peršurić i sur., 2006., 2010., 2011., Peršurić i sur. 2009., 2010., 2011).

\section{Materijal i metode}

Na osnovu podataka tadašnjeg Hrvatskog Zavoda za vinogradarstvo i vinarstvo identificirani su svi vinogradi stari od 50 do 100 godina u Istri u kojima je plemka cijepljena na ranije posađenu podlogu. Svi ti vinogradi su u narednim go- 
dinama pregledani, uz suglasnost i usmenu komunikaciju s njihovim vlasnicima ili korisnicima. Nakon detaljnog fizičkog pregleda svakog nasada tijekom vegetacije, obilježeni su svi zanimljivi trsovi, svih autohtonih i nepoznatih sorata s ciljem identifikacije njihove genetske i gospodarske vrijednosti s težištem na različitosti.

Tijekom 12-godišnjeg istraživanja, u kojem je učestvovala brojna ekipa istraživača i tehničkog osoblja Instituta, istraženo je stotinjak vinograda diljem Istarskog poluotoka. Na temelju pregleda i prikupljenih podataka iz osamdesetak nasada, označeno je više stotina biotipa različitih starih prepoznatljivih sorata vinove loze, te puno biotipova sa zanimljivim ampelografskim karakteristikama koji se nisu mogli svrstati u do tada poznate stare sorte.

Svi označeni biotipovi ampelografski su identificirani i opisani.

Deskriptori koji su korišteni za ampelografski opis grozda u berbi: OIV 202 dužina grozda; OIV 204 zbijenost grozda; OIV 206 dužina peteljke; OIV 208 oblik grozda; OIV 209 broj krila grozda; OIV 220 dužina bobice; OIV 221 širina bobice; OIV 223 oblik bobice; OIV 225 boja kožice bobice; OIV 230 boja mesa bobice; OIV 235 stupanj čvrstoće mesa bobice; OIV 236 posebnost okusa; OIV 241 prisustvo sjemenki u bobici; OIV 502 težina jednog grozda; OIV 503 težina jedne bobice te rezultate kemijske analize mošta: OIV 505 sadržaj šećera u moštu; OIV 506 sadržaj ukupnih kiselina u moštu; OIV 508 pH vrijednost mošta. Ukupni šećeri u moštu određeni su pomoću digitalnog refraktometra (Artisan TM HR200, Kanada), ukupne kiseline titracijom s 0,1 N NaOH, a pH mošta digitalnim pH metrom (Mettler Toledo MP220, Njemačka).

Uzorci tkiva listova trsova vinove loze analizirani su na tri ekonomski najbitnija virusa: Grapevine fanleaf virus (GFLV), Grapevine leafroll-associated virus 1 (GLRaV-1) i Grapevine leafroll-associated virus 3 (GLRaV-3) (Ministarstvo poljoprivrede, ribarstva i ruralnog razvoja, 2006.). Analize su izvršene DAS-ELISA testom (double-antibody sandwich enzyme-linked immunosorbent assay). Korišteni su komercijalni identikitovi proizvođača Neogen Europe Ltd, (Škotska), prema uputama proizvođača. Očitanja su smatrana pozitivnima kada se u jažicama s uzorkom pojavila žuta boja.

Nakon završetka vegetacije s označenih i šifriranih trsova, uzeta je zrela rozgva koja je u komercijalnim rasadnicima cijepljena na podloge.

Najveći dio svih biotipova tijekom 2005. do 2012. godine posađen je u novom pokusnom nasadu Gen kolekcije autohtonih sorata vinove loze na imanju Instituta za poljoprivredu i turizam u Poreču. Na površini od $7.182 \mathrm{~m}^{2}$ nalazi se posađen 3.591 trs, uspješno razmnoženih biotipova.

$\mathrm{U}$ nasadu se prate gospodarske karakteristike trsova od njihovog dolaska u rod. Taj nasad danas predstavlja osnovu za stvaranje novih klonova autohtonih sorata vinove loze $\mathrm{u}$ Istri. 


\section{Rezultati i rasprava}

S obzirom na veliku količinu podataka dobivenih u ovim višegodišnjim istraživanjima, u radu ćemo samo na primjeru Malvazije istarske prikazati kako su obrađeni svi odabrani trsovi u starim vinogradima i kako su označeni u pokusnom nasadu Gen kolekcije autohtonih sorata vinove loze na imanju Instituta za poljoprivredu i turizam u Poreču.

Na četiri lokacije - Grdoselo, Labinci, Motovunski Novaki i Peršurići odabrali smo loze Malvazije istarske bijele.

Na lokaciji Grdoselo, u blizini Pazina, četiri odabrana trsa imala su udjel šećera od 13,8 - 17,5³rixa, kiselinu 6,0 - 8,4 g/l i pH 3,0 - 3,3. Trsovi na lokaciji Peršurići, u blizini Poreča, imali su nešto više postotne udjele šećera u odnosu na lokaciju Grdoselo; 19,0 - 25,8Brixa šećera, manje kiseline 5,1 - 6,5 g/l i pH svih mošteva od 3,3.

U Labincima, blizu Poreča bili su slični parametri kvalitete mošta kao u Peršurićima. Naime postoci šećera u moštu kretali su se od $17,6-18,2^{\circ}$ Brixa, dok je kiselost bila nešto viša i kretala se od 5,8 - 7,4 g/l, pH je bio ujednačen od 3,1 do 3,3.

Na lokaciji Motovunski Novaki u blizini Motovuna, odabrani trsovi imali su $12,5-18,2^{\circ}$ Brixa šećera u moštu, kiselost 7,1 - 10,0 g/l i pH 2,9 - 3,1.

Ove razlike pripisujemo utjecaju mikrolokacije jer područja Višnjana i Kaštelira imaju više udjele šećera i niže kiseline u moštu utjecajem mediteranske klime, dok područja Grdosela, i Motovunskih Novaka u središnjoj Istri, imaju pod utjecajem kontinentalne klime manje šećera i više kiselina u moštu.

Opis bioloških obilježja pojedinih trsova klasifikacijom OIV-a obuhvaćeni su: vitice, listovi i grozdovi. Dužina vitica istovjetna je na lokacijama Grdoselo, Peršurići i Labinci, dok je na lokaciji Motovunski Novaki bitno drukčija; dužina je od srednje do vrlo duge vitice. Prema veličini lista trsovi se bitno razlikuju: na istoj lokaciji npr. Motovunski Novaki listovi su od srednje (R2 T22) do jako veliki (R1 T27). U Labicima i Peršurićima su listovi više ujednačeni: veliki, odnosno srednji. Najujednačeniji oblik plojke lista imali su trsovi u Motovunskim Novakima, dok je na ostalim lokacijama oblik plojke bio vrlo heterogen: od okruglog do peterokutnog. Antocijanska obojenost glavne nervature na plojci i naličju bila je vrlo mala ili nepostojeća. Zubci na listu bili su pravilni ili obostrano konkavni. Samo na jednoj lozi nađena je jedna konveksna, druga konkavna strana zubaca (R1 T11). Oblik sinusa zatvorenog je tipa na lokaciji Labinci, a otvorenog na lokaciji Grdoselo.

Grozdovi na lokaciji Peršurići bili su po dužini i zbijenosti najsličniji. Sličnu istovjetnost imaju trsevi lokacije Motovunski Novaki.

Zdravstveno stanje odabranih trsova bilo je zadovoljavajuće. Prema vanjskom izgledu nije bilo primjetnih znakova zaraženosti virusima (žućenje, sušenje lista, grozda i dr. znaci). Prisutnost virusa provjerili smo standardnim postupkom za de- 
tekciju virusa metodom dvojnog sendviča DAS-ELISA testom (Enzume-Linked ImmunoSorbent Assay). To je serološko-enzimski laboratorijski test $\mathrm{u}$ kombinaciji $\mathrm{s}$ indeksiranjem tj. provjerom na bezvirusnim loznim indikatorima. ELISA test detektirao je četiri virusa vinove loze: virus lepezastog lista vinove loze (GFLV), virus mozaika gušarke loze (ArMV), virus uvijenosti lišća vinove loze (GLRaV-1 i GLRaV-3).

Na lokacijima Grdoselo, na tri trsa primjećena je zaraženost virusom uvijenosti vinove loze tipa GLRaV-1, dok ostalih virusa nije bilo. Jedan trs je bio bez detektiranih virusa (R1T12). Lokacija Labinci je osim GLRaV-1 imala i zaraženost tipom GLRaV-3 na svim trsovima. Također je nađen virus GFLV. Svi trsovi na lokaciji Peršurići bili su zaraženi virusom lepezastog lista (GFLV) i virusom uvijenosti loze GLRaV-3. Na lokaciji Motovunski Novaki dokazana je nezaraženost na tri trsa (R2 T18; R1 T26; R1 T9). Trsevi R1 T27 i R1 T11 bili su zaraženi GLRaV-1 virusom uvijenosti lišća.

Istraživanje je pokazalo da postoje bitne razlike u kvaliteti mošta pojedinih lokacija, najvjerojatnije uzrokovane karakteristikama klime i biotipova na određenim lokacijama. Različitost se očitovala u količini šećera te ukupnoj kiselosti. Manju raznolikost pokazali su podaci za $\mathrm{pH}$ vrijednost.

Parametri OIV-a ukazali su na određene sličnosti odnosno različitosti: tako je nađena sličnost $u$ dužini vitica na tri lokacije (Grdoselo, Labinci). Nadalje, nađena je sličnost u veličini listova na lokacijama Labinci, Grdoselo i Motovunski Novaki. Utvrđena sortna karakteristika malvazije vrlo je mala obojenost glavne nervature lista (kako na licu, tako i na naličju) što se potvrdilo na svim lokacijama. Oblik zubaca bio je sličan - obostrani konkavni ili pravilnog oblika. Dužina i veličina grozda bila je najujednačenija na lokaciji Peršurići.

Veće razlike OIV parametara našli smo u obliku plojke lista: primjerice u Motovunskim Novakima pretežno je srcolik oblik, u Labincima peterokutan, u Grdoselo okrugao. Broj sinusa također je raznolik na svim lokacijama. Isto vrijedi za dužinu zubaca i odnos dužine zubaca i širine baze zubaca.

Zdravstveno stanje istraživanih trsova pokazala je prisutnost četiri tipa virusa. Dokazani su virus lepezastog lista, virus uvijenosti loze, virus mozaika gušarke i virus uvijenosti lišća. Na lokaciji Motovunski Novaki tri su trsa bila nezaražena virusima. 
Tablica 1. OIV parametri vitice, lista i grozda

\begin{tabular}{|c|c|c|c|c|c|c|c|c|}
\hline \multirow[b]{2}{*}{ ŠIFRA } & \multirow{2}{*}{$\begin{array}{c}\begin{array}{c}\text { Dužina } \\
\text { vitica }\end{array} \\
017\end{array}$} & \multirow{2}{*}{$\begin{array}{c}\begin{array}{c}\text { Veličina } \\
\text { lista }\end{array} \\
065\end{array}$} & \multirow{2}{*}{$\begin{array}{c}\begin{array}{c}\text { Oblik plojke } \\
\text { lista }\end{array} \\
067\end{array}$} & \multirow{2}{*}{$\begin{array}{c}\begin{array}{c}\text { Broj } \\
\text { sinusa }\end{array} \\
068\end{array}$} & \multicolumn{2}{|c|}{$\begin{array}{c}\text { Antocijanska obojenost } \\
\text { glavne nervature lica i } \\
\text { naličja lista }\end{array}$} & \multirow{2}{*}{$\begin{array}{c}\begin{array}{c}\text { Oblik } \\
\text { zubaca }\end{array} \\
076\end{array}$} & \multirow{2}{*}{$\begin{array}{c}\begin{array}{r}\text { Dužina } \\
\text { zubaca }\end{array} \\
077\end{array}$} \\
\hline & & & & & 070 & 071 & & \\
\hline \multicolumn{9}{|c|}{ GRDOSELO } \\
\hline R1 T1 & Kratka & Velik & Peterokut & Pet & $\begin{array}{l}\text { Ništa/vrlo } \\
\text { mala }\end{array}$ & $\begin{array}{l}\text { Ništa/vrlo } \\
\text { mala }\end{array}$ & $\begin{array}{l}\text { Obostrano } \\
\text { konkavni }\end{array}$ & Dugi \\
\hline R1 T81 & Kratka & Srednji & Okrugli & Pet & $\begin{array}{l}\text { Ništa/vrlo } \\
\text { mala }\end{array}$ & $\begin{array}{l}\text { Ništa/vrlo } \\
\text { mala }\end{array}$ & Pravilni & Srednji \\
\hline R1 T12 & Kratka & Velik & Okrugli & Tri & $\begin{array}{l}\text { Ništa/vrlo } \\
\text { mala }\end{array}$ & $\begin{array}{l}\text { Ništa/vrlo } \\
\text { mala }\end{array}$ & $\begin{array}{l}\text { Obostrano } \\
\text { konkavni }\end{array}$ & Srednji \\
\hline R1 T32 & Kratka & Velik & Srcolik & Pet & $\begin{array}{l}\text { Ništa/vrlo } \\
\text { mala }\end{array}$ & $\begin{array}{l}\text { Ništa/vrlo } \\
\text { mala }\end{array}$ & $\begin{array}{l}\text { Obostrano } \\
\text { konkavni }\end{array}$ & Kratki \\
\hline \multicolumn{9}{|c|}{ PERŠURIĆI } \\
\hline D 13 & - & Mali & Okrugli & Tri & $\begin{array}{l}\text { Ništa/vrlo } \\
\text { mala }\end{array}$ & $\begin{array}{l}\text { Ništa/vrlo } \\
\text { mala }\end{array}$ & $\begin{array}{l}\text { Obostrano } \\
\text { konkavni }\end{array}$ & Srednji \\
\hline D 14 & - & Srednji & Srcolik & Pet & $\begin{array}{l}\text { Ništa/vrlo } \\
\text { mala }\end{array}$ & $\begin{array}{l}\text { Ništa/vrlo } \\
\text { mala }\end{array}$ & $\begin{array}{l}\text { Obostrano } \\
\text { konkavni }\end{array}$ & Kratki \\
\hline D 15 & - & Srednji & Srcolik & Cijeli & $\begin{array}{l}\text { Ništa/vrlo } \\
\text { mala }\end{array}$ & $\begin{array}{l}\text { Ništa/vrlo } \\
\text { mala }\end{array}$ & $\begin{array}{l}\text { Obostrano } \\
\text { konkavni }\end{array}$ & Kratki \\
\hline D 16 & - & Srednji & Peterokutan & Tri & $\begin{array}{l}\text { Ništa/vrlo } \\
\text { mala }\end{array}$ & $\begin{array}{l}\text { Ništa/vrlo } \\
\text { mala }\end{array}$ & Pravilni & Kratki \\
\hline \multicolumn{9}{|l|}{ LABINCI } \\
\hline R1 T23 & Vrlo kratka & Srednji & Okrugli & Pet & $\begin{array}{l}\text { Ništa/vrlo } \\
\text { mala }\end{array}$ & $\begin{array}{l}\text { Ništa/vrlo } \\
\text { mala }\end{array}$ & Pravilni & Srednji \\
\hline R1 T33 & Srednja & Velik & Peterokutan & Pet & $\begin{array}{l}\text { Ništa/vrlo } \\
\text { mala }\end{array}$ & $\begin{array}{l}\text { Ništa/vrlo } \\
\text { mala }\end{array}$ & $\begin{array}{l}\text { Obostrano } \\
\text { konkavni }\end{array}$ & Kratki \\
\hline R3 T5 & Vrlo kratka & Velik & Peterokutan & >sedam & $\begin{array}{l}\text { Ništa/vrlo } \\
\text { mala }\end{array}$ & $\begin{array}{l}\text { Ništa/vrlo } \\
\text { mala }\end{array}$ & $\begin{array}{l}\text { Obostrano } \\
\text { konkavni }\end{array}$ & Kratki \\
\hline R3 T11 & Vrlo kratka & Velik & Srcolik & Tri & $\begin{array}{l}\text { Ništa/vrlo } \\
\text { mala }\end{array}$ & $\begin{array}{l}\text { Ništa/vrlo } \\
\text { mala }\end{array}$ & $\begin{array}{l}\text { Obostrano } \\
\text { konkavni }\end{array}$ & $\begin{array}{l}\text { Jako } \\
\text { kratki }\end{array}$ \\
\hline \multicolumn{9}{|c|}{ MOTOVUNSKI NOVAKI } \\
\hline R2 T18 & Duga & $\begin{array}{l}\text { Jako } \\
\text { velik }\end{array}$ & Srcolik & Pet & $\begin{array}{l}\text { Ništa/vrlo } \\
\text { mala }\end{array}$ & $\begin{array}{l}\text { Ništa/vrlo } \\
\text { mala }\end{array}$ & $\begin{array}{l}\text { Obostrano } \\
\text { konkavni }\end{array}$ & $\begin{array}{l}\text { Jako } \\
\text { kratki }\end{array}$ \\
\hline R2 T22 & Vrlo kratka & Srednji & Srcolik & Tri & $\begin{array}{l}\text { Ništa/vrlo } \\
\text { mala }\end{array}$ & $\begin{array}{l}\text { Ništa/vrlo } \\
\text { mala }\end{array}$ & $\begin{array}{l}\text { Obostrano } \\
\text { konkavni }\end{array}$ & Kratki \\
\hline R2 T23 & Duga & Velik & Srcolik & Tri & $\begin{array}{l}\text { Ništa/vrlo } \\
\text { mala }\end{array}$ & $\begin{array}{l}\text { Ništa/vrlo } \\
\text { mala }\end{array}$ & Pravilni & Srednji \\
\hline R1 T 18 & Duga & Srednji & Srcolik & Tri & $\begin{array}{l}\text { Ništa/vrlo } \\
\text { mala }\end{array}$ & $\begin{array}{l}\text { Ništa/vrlo } \\
\text { mala }\end{array}$ & $\begin{array}{l}\text { Obostrano } \\
\text { konkavni }\end{array}$ & Srednji \\
\hline R1 T19 & Duga & Velik & Srcolik & Tri & $\begin{array}{l}\text { Ništa/vrlo } \\
\text { mala }\end{array}$ & $\begin{array}{l}\text { Ništa/vrlo } \\
\text { mala }\end{array}$ & Pravilni & $\begin{array}{l}\text { Jako } \\
\text { kratki }\end{array}$ \\
\hline R1 T11 & Duga & Velik & Srcolik & Cijeli & $\begin{array}{l}\text { Ništa/vrlo } \\
\text { mala }\end{array}$ & $\begin{array}{l}\text { Ništa/vrlo } \\
\text { mala }\end{array}$ & $\begin{array}{l}\text { Konveksno- } \\
\text { konkavni }\end{array}$ & Srednji \\
\hline R1 T26 & Srednji & Velik & Srcolik & Tri & $\begin{array}{l}\text { Ništa/vrlo } \\
\text { mala }\end{array}$ & $\begin{array}{l}\text { Ništa/vrlo } \\
\text { mala }\end{array}$ & $\begin{array}{l}\text { Obostrani } \\
\text { konkavni }\end{array}$ & Kratki \\
\hline R1 T27 & Srednji & $\begin{array}{l}\text { Jako } \\
\text { velik }\end{array}$ & Okrugli & Cijeli & $\begin{array}{l}\text { Ništa/vrlo } \\
\text { mala }\end{array}$ & $\begin{array}{l}\text { Ništa/vrlo } \\
\text { mala }\end{array}$ & $\begin{array}{l}\text { Obostrano } \\
\text { konkavni }\end{array}$ & Kratki \\
\hline
\end{tabular}


Radovi Zavoda za znanstveni i umjetnički rad u Požegi, br. 5 (2016), str. 13-23

Đ. Peršurić, A. S. Ilak Peršurić: Gen kolekcija autohtonih sorata vinove loze u Institutu...

- nastavak tablice 1.

\begin{tabular}{|c|c|c|c|c|c|c|c|}
\hline & $\begin{array}{c}\text { Dužina } \\
\text { zubaca prema } \\
\text { širini baze } \\
\text { zubaca }\end{array}$ & $\begin{array}{l}\text { Oblik sinusa } \\
\text { peteljke }\end{array}$ & $\begin{array}{l}\text { Veličina } \\
\text { grozda }\end{array}$ & $\begin{array}{l}\text { Dužina } \\
\text { grozda }\end{array}$ & $\begin{array}{l}\text { Zbijenost } \\
\text { grozda }\end{array}$ & $\begin{array}{l}\text { Dužina } \\
\text { peteljke }\end{array}$ & \\
\hline ŠIFRA & 078 & 079 & 202 & 203 & 204 & 206 & Oblik grozda \\
\hline \multicolumn{8}{|c|}{ GRDOSELO } \\
\hline R1 T1 & Dugi & $\begin{array}{l}\text { Vrlo široko } \\
\text { otvoren }\end{array}$ & Veliki & Dugi & Zbijen & Kratki & Piramidalan \\
\hline R1 T81 & Srednji & Zatvoren & Veliki & Dugi & $\begin{array}{l}\text { Srednje } \\
\text { zbijen }\end{array}$ & Kratki & Piramidalan \\
\hline R1 T12 & Dugi & Široko otvoren & Mali & Srednji & Zbijen & Kratki & Piramidalan \\
\hline R1 T32 & Jako kratki & Otvoren & Srednji & Srednji & Zbijen & Kratki & Cilindričan \\
\hline \multicolumn{8}{|c|}{ PERŠURIĆI } \\
\hline D 13 & Srednji & Zatvoren & Srednji & Srednji & Srednje & Vrlo kratki & $\begin{array}{l}\text { Valjkasto- } \\
\text { piramidalan }\end{array}$ \\
\hline D 14 & Kratki & Poluzatvoren & Srednji & Srednji & Srednje & Kratki & Piramidalan \\
\hline D 15 & Kratki & Otvoren & Srednji & Srednji & Srednje & Vrlo kratki & $\begin{array}{l}\text { Valjkasto- } \\
\text { piramidalan }\end{array}$ \\
\hline D 16 & Kratki & Poluzatvoren & Srednji & Srednji & Zbijen & Kratki & Cilindričan \\
\hline \multicolumn{8}{|l|}{ LABINCI } \\
\hline R1 T23 & Srednji & $\begin{array}{l}\text { Vrlo malo } \\
\text { prekrit }\end{array}$ & Veliki & Dugi & Zbijen & Vrlo kratki & $\begin{array}{l}\text { Valjkasto- } \\
\text { piramidalan }\end{array}$ \\
\hline R1 T33 & Kratki & Poluzatvoren & Veliki & Dugi & Rastresit & Vrlo kratki & Razgranati \\
\hline R3 T5 & Kratki & Poluzatvoren & Srednji & Srednji & Rastresit & Vrlo kratki & Piramidalan \\
\hline R3 T11 & Jako kratki & Poluzatvoren & Mali & Kratki & Srednji & Vrlo kratki & Cilindričan \\
\hline \multicolumn{8}{|c|}{ MOTOVUNSKI NOVAKI } \\
\hline R2 T18 & Jako kratki & Poluzatvoren & Veliki & Dugi & Srednji & Vrlo kratki & Piramidalan \\
\hline R2 T22 & Kratki & Otvoren & Srednji & Dugi & Zbijen & Vrlo kratki & $\begin{array}{l}\text { Valjkasto- } \\
\text { piramidalan }\end{array}$ \\
\hline R2 T23 & Srednji & Poluzatvoren & Srednji & Dugi & Srednji & Srednji & Piramidalan \\
\hline $\mathrm{R} 1 \mathrm{~T} 18$ & Srednji & Široko otvoren & Veliki & Dugi & Zbijen & Vrlo kratki & Piramidalan \\
\hline R1 T19 & Kratki & Poluzatvoren & Veliki & Dugi & Zbijen & Kratki & $\begin{array}{l}\text { Valjkasto- } \\
\text { piramidalan }\end{array}$ \\
\hline R1 T11 & Kratki & Poluzatvoren & Srednji & Dugi & Zbijen & Kratki & $\begin{array}{l}\text { Valjkasto- } \\
\text { piramidalan }\end{array}$ \\
\hline R1 T26 & Srednji & $\begin{array}{l}\text { Vrlo široko } \\
\text { otvoren }\end{array}$ & Veliki & Dugi & Zbijen & Vrlo kratki & $\begin{array}{l}\text { Valjkasto- } \\
\text { piramidalan }\end{array}$ \\
\hline R1 T27 & Srednji & Zatvoren & Veliki & Dugi & Zbijen & Kratki & Krilati \\
\hline
\end{tabular}

Izvor: istraživanje 
Od 57 redova s po 63 trsa u tablici 2., na primjeru 24. reda, prikazan je način na koji je ustrojen cijeli pokusni nasad Gen kolekcije autohtonih sorata vinove loze na imanju Instituta za poljoprivredu i turizam u Poreču.

Tablica 2. Prikaz trsova autohtonih sorata u pokusnom nasadu Instituta u Poreču

RED 24 - SADNJA 2006:

\begin{tabular}{|c|c|c|c|c|c|}
\hline Red & $\begin{array}{l}\text { Sadno } \\
\text { mjesto }\end{array}$ & Sorta & Podloga & Šifra & Broj trsova \\
\hline 24 & 1 & Malvazija istarska & $\mathrm{SO} 4$ & SR 3 & 7 \\
\hline 24 & 2 & Malvazija istarska & $\mathrm{SO} 4$ & SR 3 & 7 \\
\hline 24 & 3 & Malvazija istarska & $\mathrm{SO} 4$ & SR 3 & 7 \\
\hline 24 & 4 & Malvazija istarska & $\mathrm{SO} 4$ & SR 3 & 7 \\
\hline 24 & 5 & Malvazija istarska & $\mathrm{SO} 4$ & SR 3 & 7 \\
\hline 24 & 6 & Malvazija istarska & $\mathrm{SO} 4$ & SR 3 & 7 \\
\hline 24 & 7 & Malvazija istarska & $\mathrm{SO} 4$ & SR 3 & 7 \\
\hline 24 & 8 & Muškat momj. & $\mathrm{SO} 4$ & JURC 5 & 3 \\
\hline 24 & 9 & Muškat momj. & $\mathrm{SO} 4$ & JURC 5 & 3 \\
\hline 24 & 10 & Muškat momj. & $\mathrm{SO} 4$ & JURC 5 & 3 \\
\hline 24 & 11 & Malvazija istarska & $\mathrm{SO} 4$ & SE 6 & 3 \\
\hline 24 & 12 & Malvazija istarska & $\mathrm{SO} 4$ & SE 6 & 3 \\
\hline 24 & 13 & Malvazija istarska & $\mathrm{SO} 4$ & SE 6 & 3 \\
\hline 24 & 14 & Teran & $\mathrm{SO} 4$ & RI 1 (a) & 7 \\
\hline 24 & 15 & Teran & $\mathrm{SO} 4$ & RI 1 (a) & 7 \\
\hline 24 & 16 & Teran & $\mathrm{SO} 4$ & RI 1 (a) & 7 \\
\hline 24 & 17 & Teran & $\mathrm{SO} 4$ & RI 1 (b) & 7 \\
\hline 24 & 18 & Teran & $\mathrm{SO} 4$ & RI 1 (b) & 7 \\
\hline 24 & 19 & Teran & $\mathrm{SO} 4$ & RI 1 (b) & 7 \\
\hline 24 & 20 & Teran & $\mathrm{SO} 4$ & RI 1 (b) & 7 \\
\hline 24 & 21 & Malvazija istarska & $\mathrm{SO} 4$ & SE2 & 28 \\
\hline 24 & 22 & Malvazija istarska & $\mathrm{SO} 4$ & SE2 & 28 \\
\hline 24 & 23 & Malvazija istarska & $\mathrm{SO} 4$ & SE2 & 28 \\
\hline 24 & 24 & Malvazija istarska & $\mathrm{SO} 4$ & SE2 & 28 \\
\hline 24 & 25 & Malvazija istarska & $\mathrm{SO} 4$ & SE2 & 28 \\
\hline 24 & 26 & Malvazija istarska & $\mathrm{SO} 4$ & SE2 & 28 \\
\hline 24 & 27 & Malvazija istarska & $\mathrm{SO} 4$ & SE2 & 28 \\
\hline \multirow[t]{2}{*}{24} & 28 & Malvazija istarska & $\mathrm{SO} 4$ & SE2 & 28 \\
\hline & & & $\begin{array}{c}\text { Prijelom } \\
\text { tablice od } \\
29 . \text { do } 42 . \\
\text { trsa } \\
\end{array}$ & & \\
\hline 24 & 43 & Malvazija istarska & $\mathrm{SO} 4$ & SE2 & 28 \\
\hline 24 & 44 & Malvazija istarska & $\mathrm{SO} 4$ & SE2 & 28 \\
\hline
\end{tabular}




\begin{tabular}{cccccc}
\hline $\mathbf{2 4}$ & 45 & Malvazija istarska & SO4 & SE2 & 28 \\
\hline $\mathbf{2 4}$ & 46 & Malvazija istarska & SO4 & SE2 & 28 \\
\hline $\mathbf{2 4}$ & 47 & Malvazija istarska & SO4 & SE2 & 28 \\
\hline $\mathbf{2 4}$ & 48 & Malvazija istarska & SO4 & SE2 & 28 \\
\hline $\mathbf{2 4}$ & 49 & Teran & SO4 & PE11 & 9 \\
\hline $\mathbf{2 4}$ & 50 & Teran & SO4 & PE11 & 9 \\
\hline $\mathbf{2 4}$ & 51 & Teran & SO4 & PE11 & 9 \\
\hline $\mathbf{2 4}$ & 52 & Teran & SO4 & PE11 & 9 \\
\hline $\mathbf{2 4}$ & 54 & Teran & SO4 & PE11 & 9 \\
\hline $\mathbf{2 4}$ & 55 & Teran & SO4 & PE11 & 9 \\
\hline $\mathbf{2 4}$ & 56 & Teran & SO4 & PE11 & 9 \\
\hline $\mathbf{2 4}$ & 57 & Teran & SO4 & PE11 & 9 \\
\hline $\mathbf{2 4}$ & 58 & Teran & SO4 & PE11 & 9 \\
\hline $\mathbf{2 4}$ & 59 & Malvazija istarska & SO4 & SR4 & 1 \\
\hline $\mathbf{2 4}$ & 60 & Malvazija istarska & SO4 & PE6 & 5 \\
\hline $\mathbf{2 4}$ & 61 & Malvazija istarska & SO4 & PE6 & 5 \\
\hline $\mathbf{2 4}$ & 62 & Malvazija istarska & SO4 & PE6 & 5 \\
\hline $\mathbf{2 4}$ & 63 & Malvazija istarska & SO4 & PE6 & 5 \\
\hline
\end{tabular}

\section{Zaključci}

Gen kolekcija Instituta osnova je za dugoročni i održivi razvoj vinogradarstva u Istri, jer ne postoji nijedan matični nasad vinove loze podignut sukladno važećim zakonskim propisima, koji bi bio izvor kvalitetnog sadnog materijala autohtonih sorata genetskog porijekla iz Istre.

S obzirom na istraženu i utvrđenu veliku sortnu raznolikost materijala vinove loze proučavanih tijekom obilaska starih vinograda s lozom cijepljenom na mjestu sadnje te sadnju odabranog materijala na stalno mjesto u Gen kolekciji Instituta u podjednakim klimatskim i pedološkim uvjetima za sve odabrane sorte, moguća su daljnja istraživanja biološke raznolikosti i genetskog potencijala autohtonih istarskih sorata vinove loze u njihovom prirodnom i kulturološkom okružju u svrhu unapređenja vinogradarstva i vinarstva.

\section{Literatura}

Busnengo, Aldo (1998), Aspetti legislativi di settore: le politice comunitarie. Simposio Internazionale Territorio e vino. La Zonazione strumento di conoscenza per la qualita". Siena. 
Bratović, Ivan, Peršurić, Đordano, Milotić, Aldo (2000), Ekološko sociološki aspekti vinogradarstva u Istri. Book of invited papers and Abstracts. Pejić, I., Mirošević, N. (ur.). Zagreb. Agronomski fakultet u Zagrebu, 57-57.

Ilak Peršurić Anita Silvana, Peršurić Đordano, Sinčić Matea, Petrušić Danijela, Godena Sara, (2010), Ampelografske karakteristike Malvazije istarske Zbornik radova 45. hrvatski \& 5. međunarodni znanstveni simpozij agronoma. (ed.) Marić S. 11671171. Osijek, Poljoprivredni fakultet Sveučilišta J.J. Strossmayer u Osijeku.

Ilak Peršurić, Anita Silvana, Peršurić, Đordano, Gluhić, David (2006), Istraživanje bioraznolikosti Malvazije Istarske bijele temeljem OIV parametara. Sjemenarstvo 3 (23): 255-272.

Ilak Peršurić, Anita Silvana, Težak Ana (2011), Wine production on Istria family farms. Acta agriculturae Slovenica, 97(1):25-31.

Mannini, Franco (2003), Grapevine clonal and sanitary inspection: In the point of view of E.U. selectors. Abstr. Locorotondo, Italija, pp.150.

Milotić, Aldo, Cargnello, Giovanni, Peršurić, Đordano (1999),"Great" vitiviniculture zonation in Istria, researches and various considerations, XI giornate GESCO. Barbagallo, Maria Gabriella (ur.). Palermo : Facolta di agraria, 825-832.

Peršurić Đordano, Ilak Peršurić, Anita Silvana, Godena, Sara, Sinčić Matea, Petrušić Danijela, 2011. Ampelografska analiza i zdravstveno stanje sorti Surina, Pagadebit istarski i Opaćevina (Vitis vinifera L.) u Istri. Zbornik radova 46. hrvatski $\mathcal{E} 6$. međunarodni znanstveni simpozij agronoma. 976-979.

Peršurić Đordano, Gluhić, David, Ilak Peršurić Anita Silvana (2010), Pregled istraživanja šest sorata vinove loze u Istri. Sjemenarstvo 4/2009: 307-316.

Peršurić, Đordano, Ilak Peršurić, Anita Silvana, Težak, Ana (2009), Wine Offer in Istrian Wine Cellars. 32nd World Congress of Vine and Wine and 7th General Assembly of the OIV: proceedings, 28.06.-03.07.2009, Zagreb, ISBN: 978-953-6718-12-2. 


\section{The Gene Collection of Autochthonous Wine Grape Varieties at the Institute as a Contribution to the Sustainable Development of Wine Growing and Viticulture in Istria}

\section{Summary}

During a number of years, the world trends are preserving and creating a sustainable development of viticulture, based upon origin and typical varieties in certain wine growing areas. Scientific research conducted since 2003 within the project Genetic and economical resources of Vitis sp., started in 2003 and continued in 2006 with the project Valorisation of wine grapes (Vitis sp.) and gene bank (2006-2012), autochthonous sorts of wine grapes were thoroughly examined throughout Istria, with the aim of economical and genetic valorisation.

Following 12 years of field research, with the commitment of a large group of scientists and technical personnel from the Institute, around a hundred vineyards were examined throughout Istria. In order to find and identify the old Istria varieties, examined vineyards were 50 to 100 years of age, grafted in situ, containing different genetic and economical characteristics. Based upon field research on hundreds of wine stocks and gathered data from eighty vineyards, numerous biotypes that could not be set in the context of the already known old varieties, with interesting ampelographic characteristics, were identified.

All biotypes were ampelographically identified and described. Morphological characteristics were described with OIV indicators. Chemical analysis of must was conducted $(\mathrm{pH}$, content of sugar, acidity), as well as the DAS-ELISA test for sanitary condition.

The majority of selected biotypes collected during 2005-2012 were grafted on the new trial plots Gene Collection of autochthonous wine grape varieties on the land belonging to the Institute of Agriculture and Tourism in Poreč. On the plots of 7,182 $\mathrm{m}^{2}$, we have successfully planted 3,591 wine stocks. This plantation is today a base for creating new clones of autochthonous sorts in Istria.

The Gene Collection is a base for long-term and sustainable development in Istria, as there exist no matricular plantations of wine grapes according to current laws that could be a source of quality seedling material with genetic origin from Istria.

Keywords: Vitis sp.; viticulture; autochthonous wine grapes varieties; Gene Collection; sustainable development.

Dr. sc. Đordano Peršurić

Institut za poljoprivredu i turizam

K. Hugues 8, 52440 Poreč

djordano@iptpo.hr

Dr. sc. Anita Silvana Ilak Peršurić

Institut za poljoprivredu i turizam

K. Hugues 8, 52440 Poreč

anita@iptpo.hr 